\title{
Flowering phenology in the arid winter rainfall region of southern Africa
}

\author{
M. STRUCK*
}

Keywords: climatic variables, Howering sequence, Namanualand, phenology, precipitation, seasonality, Succulent Karex, temperature, timing, vigour of bloming

\section{ABSTRACT}

\begin{abstract}
The impact of physical factors on the llowering phenology of a succulent karroid community in the winter rainfall region of the northwestern Cape, South Africa, based upon a three year study on permanent plots, is examined. On the permanent plots. flowering of the shnuby species extended over a period of $4104 \frac{1}{2}$ months each year, while blooming of the therophytes peaked in the first half of the flowering season. Species composition and numbers of individuals in the therophytes and geophytes offering flowers varied greatly according to the pattern and amount of seasonal precipitation. Despite these variations a consistent flowering sequence between the years was observed. Possible relations between the flowering phenology and the climatic variables are discussed in detail. The present data suggest that the onset of flowering is determined indirectly by the first drop in temperature in autumn. indicating the beginning of the rainy season and presumably the start of the growing period, and/or by the increase of temperatures in the beginning of spring. The pattem and amount of rainfall within a given season mainly influenced the duration of anthesis and the number of flowers produced.
\end{abstract}

\section{UITTREKSEI}

Die invloed van fisiese faktore op die blomfenologie van 'n sukkulente karoogemeenskap in die winterreeingebied van die Noxrdwes-Kitap, Suid-Afrika, gebaseer op 'n dricjalar-studie op permanente persele, is ondersoek. Die blomperiode van die struikagtige spesies op die permanente persele was versprei oor $n$ periode van 4 tot $41 / 2$ maande elke jaar. terwyl die blomperiode by die terofiete gedurende die eerste helfte van die blomseisoen "n spits bereik het. Spesiesamestelling en aantal individue by die terofiete en geofiete wat blom, is sterk beinvloed deur die patroon en hoeveelheid van die jaarlikse neerslag. Ondanks hierdie variasies is "n reëlmatige blomopeenvolging oor die drie jaar waargeneem. Moontlike verhoudings tussen die blomfenologie en die klimatweranderlikes word in besonderhede bespreck. Die huidige data dui daarop dat die begin van die blomseisen indirek bepaal word deur 'n afname in temperatuur gedurende die herts, wat die begin van die reënseisoen en moontlik die he gin van die groeiseiseen aandui, en/of deur die toename in temperatuur aan die begin van die lente. Die patroon en hoevectheid reènval binne "n gegewe seisoen beinvloed hoofsaaklik dic duur van antese en die aantal blomme wat gevorm word.

\section{INTROIDUCTION}

A short but copious blooming is a characteristic feature of many arid and semi-arid regions. This is particularly true of Namaqualand in the northwestern Cape, South Africa, which is renowned for its flower displays during springtime.

For most plant species the growing season is restricted to the cool and moist autumn-winter-spring period and the dormant season occurs during the hot and dry summer months. The growing period usually commences in autumn (March to April) with the sprouting of the perennials and the germination of the therophytes (Van Rooyen et al. 1979: Le Roux et al. 1989). The flowering season lasts from late winter to spring (August to early October). During this period $90 \%$ of the shrubby perennials and virtually all the annuals are blooming (Le Roux et al. 1989). In comparison to other regions of winter rainfall climate anthesis is markedly synchronized (Orshan et al. 1989).

The overall influence of the climatic factors on the phenological events in arid regions is obvious. With respect to the phenology of flowering, special attention has been given to the timing and synchrony of blooming in relation

* Botany Department, University of Cape Town, Private Bag. Rondehosch $77(x)$. to the influence of climatic variables (c.g. Baker et al. 1982; Beatley 1974; Noy-Meir 1973; Solbrig \& Yang 1977). Generally, the importance of an opportunistic response by the plants to water availability has been stressed. Compared to other arid areas receiving a similar amount of average rainfall, the predictability of seasonal precipitation is relatively high in the arid winter rainfall region of the Cape Province (Hoffman \& Cowling 1987). Hence, the phenology of the vegetation should be comparatively predictable, too). However, the question of the impact of current seasonal weather conditions on the flowering phenology has not yet been addressed adequately.

Against this background, results of a three year study of the flowering phenology of a succulent karroid community of the northwestern Cape are presented. The following questions shall be addressed in particular: 1, how does the timing and vigour of flowering vary between the years?; and 2, can the phenological pattern be linked to the current rainfall and/or temperature conditions, thus indicating potential environmental cues? The present survey is clearly constrained by the limited number of plots and years studied. and the data do not provide a robust basis for a thorough statistical evaluation. Hence, the following observations should be regarded as indicating trends. 
METHODS

The field work was carried out at the Goegap Nature Reserve during the blooming seasons of the years 1985 (late June to October), 1986 (July to late November), and 1987 (mid-August to mid-November).

The records of the actual temperatures and precipitation at Goegap were provided by the authorities of Goegap Nature Reserve. The data were supplemented by the author with the aid of a thermohygrograph.

Phenological data were collected for a total of 112 plant species on six permanent plots of $100 \mathrm{~m}^{2}$, each. Five plots were laid out on various sites on a mountain slope with undisturbed dwarf-scrub vegetation so as to cover some of the conspicuous variation in species composition. One plot was marked on a sandy plain with exclusively ephemeral vegetation showing a particularly high degree of variation in yearly species composition and plant cover. The permanent plots are characterized in an Appendix.

For each species onset and duration of anthesis were recorded. Furthermore, numbers of open flowers or inflorescences with open flowers were repeatedly counted at time intervals of three to five (rarely up to seven) days. Inflorescences and partial inflorescences representing the functional unit of visitor attraction or pollination (i.e. blossoms sensu Faegri \& Van der Pijl 1979) were taken as equivalent to single flowers.

Plant names are mostly according to Gibbs Russell et al. $(1985,1987)$.

\section{STUDY SITE}

\section{Description of the study site}

The Goegap Nature Reserve is situated $12 \mathrm{~km}$ east of Springbok (between S $29^{\circ} 34^{\prime}$ and $29^{\circ} 41^{\prime}$ and E $17^{\circ} 57^{\prime}$ and $18^{\circ} 02^{\prime}$ ) in the Namaqualand Rocky Hills in the northwestern Cape, South Africa.
The area is characterized by an open dwarf-scrub vegetation which has been classified as "Namaqualand Broken Veld' by Acocks (1988) and as part of the Succulent Karoo Biome by Rutherford \& Westfall (1986). Succulent and narrow-leaved sclerophyllous species abound. The flora is clearly dominated by Asteraceae and Mesembryanthemaceae (Le Roux 1984).

The study area is situated in the realm of the winter rainfall region. About $70 \%$ of the yearly precipitation is received from April to October and about $38 \%$ during the wettest quarter of the year (June to August) (Table 1). Drought conditions prevail virtually throughout the year. All climatic factors are subject to conspicuous annual fluctuations.

\section{Weather conditions during the study}

The amount of precipitation as well as the timing and number of rain events varied considerably between the study years (Figure 1; Tables $1 \& 2$ ). Annual rainfall was highest in $1985(244.5 \mathrm{~mm}$, i.e. $73 \%$ above the average for the years 1974 to 1987), but much lower in both of the subsequent years $(110.5 \mathrm{~mm}$ in 1986 , i.e. $22 \%$ below the average and $113.5 \mathrm{~mm}$ in 1987, i.e. $20 \%$ below the average). However, rainfall figures for the main growth period (April to October) and wettest quarter of a year (June to August) provide quite a different picture (Tables $1 \& 2$ ). During the main growth period, $87 \mathrm{~mm}$ was received in 1985 (35.6\% of the year's total), $81.5 \mathrm{~mm}$ in $1986(73.7 \%$ of the year's total) and $113.5 \mathrm{~mm}$ in 1987 (100\% of the year's total). The maximum number of rainy days was recorded in 1986, especially between June and mid-September. The relatively high rainfall of 1987 was due to several exceptionally good rains during April, June, and August. In contrast, in 1985 drought conditions prevailed in June and during August to September with only few intermediate rains.

In comparison to the rainfall pattern the annual course of air temperatures was rather uniform (Figure 1). In each year, winter minimum values were reached during a pe-

TABLE 1.-Rainfall (mm) in Goegab Nature Reserve 1974-1987, calculated from data from Le Roux (1984) and unpublished weather data of the Reserve

\begin{tabular}{|c|c|c|c|c|c|c|c|c|c|c|c|c|}
\hline \multirow[b]{2}{*}{$\begin{array}{l}1974 \\
1987\end{array}$} & \multirow[b]{2}{*}{$\begin{array}{c}\text { Mean } \\
\text { monthly \& } \\
\text { annual }\end{array}$} & \multirow[b]{2}{*}{$\begin{array}{l}\text { Stand. } \\
\text { devia- } \\
\text { tion }\end{array}$} & \multirow[b]{2}{*}{$\begin{array}{l}\text { Coeffic. } \\
\text { of } \\
\text { variation }\end{array}$} & \multicolumn{2}{|c|}{1985} & \multicolumn{2}{|c|}{1986} & \multicolumn{2}{|c|}{1987} & \multicolumn{2}{|c|}{$1974-1987$} & \\
\hline & & & & $\mathrm{mm}$ & $\begin{array}{l}\% \text { of } \\
\text { annual } \\
\text { rainfall }\end{array}$ & $\mathrm{mm}$ & $\begin{array}{c}\% \text { of } \\
\text { annual } \\
\text { rainfall }\end{array}$ & $\mathrm{mm}$ & $\begin{array}{l}\% \text { of } \\
\text { annual } \\
\text { rainfall }\end{array}$ & $\mathrm{mm}$ & $\begin{array}{l}\text { \% of } \\
\text { annual } \\
\text { rainfall }\end{array}$ & \\
\hline Feb. & 10.0 & 21.7 & 217.0 & & & & & & & & & \\
\hline Mar. & 13.2 & 13.3 & 100.7 & & & & & & & & & \\
\hline Apr. & 10.9 & 9.1 & $83 . \overline{5}$ & & & & & & & & & \\
\hline May & 15.5 & 20.8 & 134.2 & & & & & & & & & \\
\hline Jun. & 18.2 & 15.6 & 85.7 & & & & & & & & & \\
\hline Jul. & 19.3 & 18.2 & 94.3 & 20.5 & 8.4 & 59.0 & 53.4 & 71.0 & 62.5 & 54.3 & 38.3 & $\begin{array}{l}\text { Wettest quarter } \\
\text { (June to Aug.) }\end{array}$ \\
\hline Aug. & 16.8 & 13.7 & 81.5 & & & & & & & & & \\
\hline Sept. & 7.1 & 8.3 & $116.9>$ & 87.0 & 35.6 & 81.5 & 73.7 & 113.5 & 100.0 & 98.3 & 69.4 & Main growth \\
\hline Oct. & 11.2 & 7.8 & 69.6 & & & & & & & & & spr. (o Uct.) \\
\hline Nov. & 4.7 & 6.8 & 144.7 & & & & & & & & & \\
\hline Dec. & 9.0 & 23.9 & 265.5 & 110.4 & 45.1 & 19.5 & 17.6 & 0.0 & 0.0 & 19.4 & 13.7 & $\begin{array}{l}\text { Driest quarter } \\
\text { (Nov. to Jan.) }\end{array}$ \\
\hline Jan. & 5.7 & 10.3 & 180.7 & & & & & & & & & \\
\hline Total & 141.6 & 63.1 & 44.6 & 244.5 & & 110.5 & & 113.5 & & 141.6 & & \\
\hline
\end{tabular}



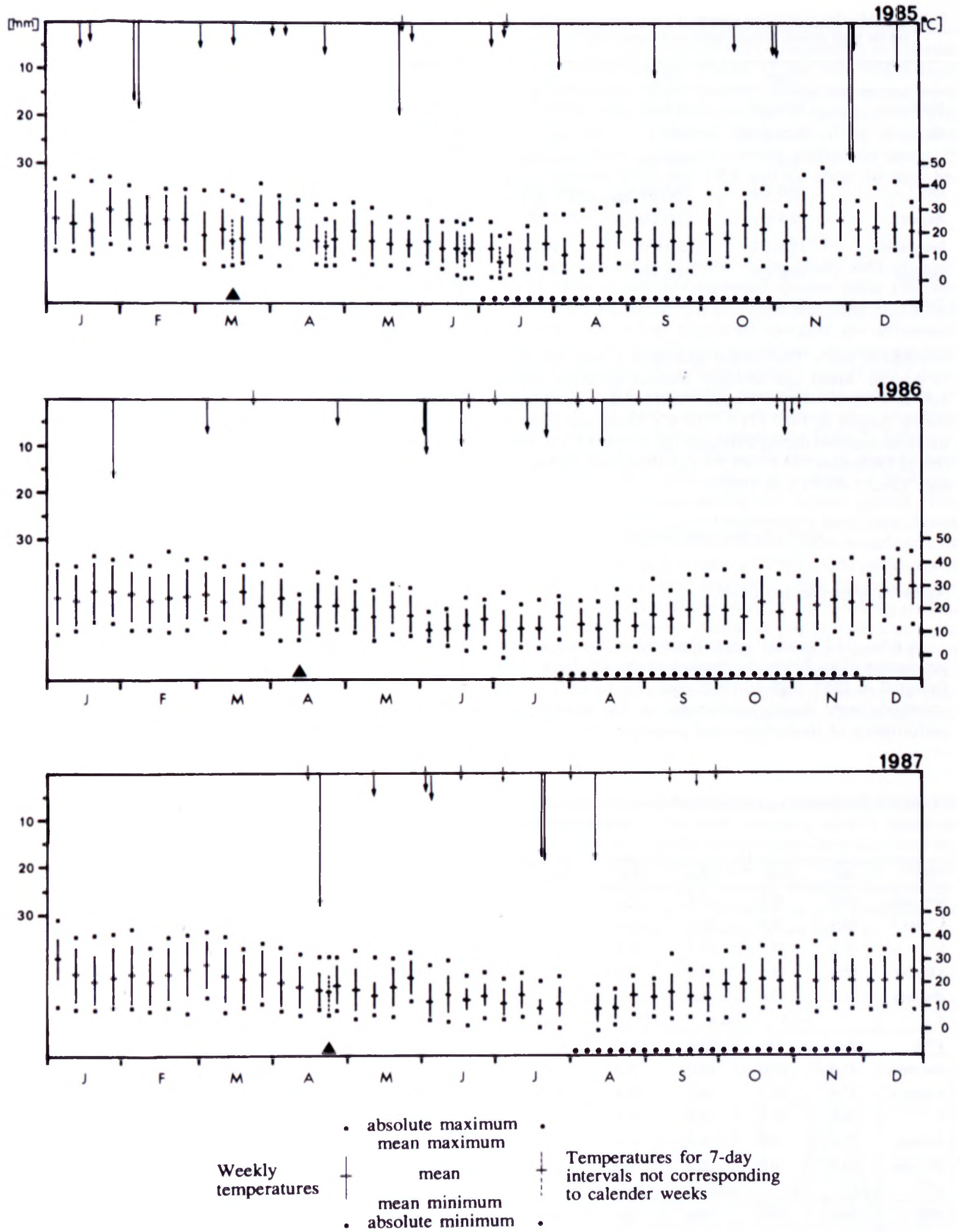

FIGURE 1, - Rainfall and temperature conditions in Geregab Nature Reserve during the study period. $\mathbf{A}$, autumnal drop in temperature; ....., yearly flowering period: $\downarrow$, rainfall (further details see text).

riod of about five months, after which temperatures increased again during a period of one to two months to reach summer values (Table 3 ). Nevertheless, the onset of the cool season appeared to shift from year to year. In 1985 the mean monthly temperatures dropped considerably during March, but only during April in both of the 
TABLE 2.-Monthly rainfall and number of rainy days (in brackets) during the main growth period (April to October) 1985 to 1987

\begin{tabular}{lccc}
\hline \hline & 1985 & 1986 & 1987 \\
\hline April & $13.0(3)$ & $6.0(1)$ & $31.0(2)$ \\
May & $25.5(3)$ & 0.0 & $5.0(1)$ \\
June & 0.0 & $30.5(4)$ & $11.5(3)$ \\
July & $10.0(3)$ & $15.5(3)$ & $39.0(3)$ \\
August & $10.5(1)$ & $13.0(4)$ & $20.5(2)$ \\
September & $12.5(1)$ & $2.0(1)$ & $5.0(2)$ \\
October & $15.5(2)$ & $14.5(4)$ & $1.5(1)$ \\
Total & $87.0(13)$ & $81.5(17)$ & $113.5(14)$ \\
\hline
\end{tabular}

subsequent years. The coldest quarter of a year was June to August. Mean and absolute minima occurred during July in $1985\left(13.8 / 1.0^{\circ} \mathrm{C}\right)$ and $1986\left(12.8 /-1.0^{\circ} \mathrm{C}\right)$, but during August in $1987\left(11.6 / 0.5^{\circ} \mathrm{C}\right)$. Mean and absolute maxima occurred during February $\left(26.3 / 48.0^{\circ} \mathrm{C}\right)$ in 1985 , during December $\left(28.2 / 45.5^{\circ} \mathrm{C}\right)$ in 1986 , and during January $\left(26.2 / 48.0^{\circ} \mathrm{C}\right)$ in 1987 .

\section{RESULTS AND DISCUSSION}

\section{Numbers of species in flower}

In total, 112 species were observed in flower on the permanent plots during the present study. Of these, $44 \%$ flowered in 1985, 95\% in 1986, and $79 \%$ in 1987. These variations were mainly attributable to the phenological performance of therophytes and geophytes (Table 4).
The number of therophytic species flowering in a given year seems to be related to the amount and distribution of rainfall occurring durirg the two months before the onset of the flowering season. In 1985 only $25.5 \mathrm{~mm}$ fell during this period, whereas in both of the subsequent years the figure was nearly twice as high (1986: $46 \mathrm{~mm}, 1987$ : $50.5 \mathrm{~mm}$; Table 2; Figure 1).

In 1985, the flowering was also affected by unfavourable weather conditions during the flowering period itself, as shown in Figure 2. In that year, a dry period set in after the initial rains at the onset of the blooming season (Figure 1 and Table 2) causing drought stress particularly for the therophytes. A good rain in mid-September, however, stimulated active growth and flowering.

Very few plant species growing on the permanent plots flowered during summer. These are Othonna furcata (March and April), Tylecodon wallichii (end of November to beginning of December), the therophyte Tribulus terrestris (April), and the hysteranthous geophyte Eriospermum paradoxum (March and April; all dates after Van Rooyen et al. 1979).

\section{Timing and sequence of flowering}

In each year, the blooming season lasted 4 to $41 / 2$ months. However, the exact timing varied markedly between the years. In 1985, most plants flowered from early July until the end of October, whereas in both of the subsequent years blooming commenced about four weeks later, in early August, and continued until the end of November (Figure 1).

TABLE 3.-Temperature regime in Goegab during the study period 1985 to 1987. Data from unpublished weather report Goegab Nature Reserve and own measurements by thermohygrograph

\begin{tabular}{|c|c|c|c|c|c|c|c|c|c|c|c|c|}
\hline 1985 & Jan. & Feb. & Mar. & Apr. & May & Jun. & Jul. & Aug. & Sep. & Oct. & Nov. & Dec. \\
\hline abs. max. & 44.0 & 40.0 & 41.0 & 36.0 & 33.0 & 26.5 & 28.5 & 32.0 & 34.0 & 39.5 & 48.0 & 42.5 \\
\hline$x(\max )$. & 34.9 & 35.4 & 30.7 & 27.7 & 24.5 & 21.9 & 19.9 & 22.7 & 25.3 & 30.8 & 35.7 & 30.3 \\
\hline$x$ & 25.2 & 25.7 & 21.1 & 20.4 & 17.6 & 15.0 & 13.8 & 15.6 & 16.8 & 21.2 & 26.3 & 22.0 \\
\hline$x(\min )$. & 15.6 & 16.1 & 11.5 & 13.0 & 10.7 & 8.1 & 7.7 & 8.5 & 8.3 & 11.6 & 16.9 & 13.7 \\
\hline abs. min. & 11.0 & 13.0 & 6.0 & 6.0 & 5.0 & 1.5 & 1.0 & 3.0 & 3.5 & 6.5 & 5.0 & 10.0 \\
\hline d & & +0.5 & -4.6 & -0.7 & -2.8 & -2.6 & -1.2 & +1.8 & +1.2 & +4.4 & +5.1 & -4.3 \\
\hline 1986 & Jan. & Feb. & Mar. & Apr. & May & Jun. & Jul. & Aug. & Sep. & Oct. & Nov. & Dec. \\
\hline abs. max. & 43.0 & 43.0 & 42.0 & 39.0 & 32.0 & 25.0 & 28.0 & 29.0 & 35.0 & 38.5 & 42.5 & 45.5 \\
\hline$x(\max )$. & 37.4 & 35.3 & 34.3 & 29.8 & 27.3 & 18.7 & 18.9 & 19.7 & 26.2 & 28.7 & 31.8 & 37.8 \\
\hline$x$ & 26.4 & 25.2 & 25.6 & 21.6 & 19.4 & 13.0 & 12.8 & 13.5 & 18.2 & 19.7 & 21.8 & 28.2 \\
\hline$x(\min )$. & 15.4 & 15.0 & 16.9 & 13.4 & 11.6 & 7.2 & 6.7 & 7.2 & 10.2 & 10.7 & 11.7 & 18.6 \\
\hline abs. min. & 10.0 & 10.0 & 10.0 & 6.0 & 6.0 & 2.0 & -1.0 & 3.0 & 3.5 & 3.5 & 3.5 & 8.0 \\
\hline d & +4.4 & -1.2 & +0.4 & -4.0 & -2.2 & -6.4 & -0.2 & +0.7 & +4.7 & +1.5 & +2.1 & +6.4 \\
\hline 1987 & Jan. & Feb. & Mar. & Apr. & May & Jun. & Jul. & Aug. & Sep. & Oct. & Nov. & Dec. \\
\hline abs. max. & 48.0 & 44.0 & 43.0 & 36.0 & 35.0 & 30.0 & $25 .()$ & 23.0 & 33.0 & 36.0 & 41.0 & 42.0 \\
\hline$x(\max )$. & 36.6 & 34.4 & 35.4 & 28.5 & 25.8 & 20.3 & 17.6 & 17.0 & 21.1 & 28.4 & 31.7 & 32.4 \\
\hline$x$ & 26.2 & 24.1 & 24.9 & 19.8 & 18.5 & 14.5 & 12.5 & 11.6 & 15.0 & 20.6 & 21.8 & 22.3 \\
\hline$x(\min )$. & 15.7 & 13.7 & 14.5 & 11.0 & 11.2 & 8.7 & 7.5 & 6.3 & 9.0 & 12.9 & 12.0 & 12.1 \\
\hline abs. min. & 10.0 & 8.0 & 9.0 & 7.0 & 5.0 & 3.0 & 1.5 & 0.5 & 5.0 & 6.5 & 8.5 & 8.0 \\
\hline $\mathrm{d}$ & -2.0 & -1.1 & +0.8 & -5.1 & -1.3 & -4.0 & -2.0 & -0.9 & +3.4 & +5.6 & +1.2 & $+(1) .5$ \\
\hline
\end{tabular}

x, mean monthly temperature: $x$ (max.). mean maxima: $x$ (min.). mean minima; abs. max., absolute maxima; abs. min., absolute minima; d, differences between means of consecutive months. 
TABLE 4.-Number of thowering species observed on the permanent plots listed according to their life form

\begin{tabular}{ccccc}
\hline & $\begin{array}{c}\text { Chamiephytes } \\
\text { Namo- } \\
\text { phancroph. }\end{array}$ & Geophytes & Therophytes & Total \\
\hline 1985 & 30 & 5 & 14 & 49 \\
1986 & 33 & 5 & 69 & 107 \\
1987 & 30 & 10 & 48 & 88 \\
\hline
\end{tabular}

Despite the temporal fluctuation in the onset of the flowering season the sequence of flowering of the species involved remained nearly constant (see flowering sequence for plot 1 in Figure 3), i.e. independent of the current pattern of precipitation in a given year. Such consistent sequences of flowering phenologies have been described from areas of virtually all climatic zones (Heinrich 1976; Heithaus 1974; Hocking 1968; Kratochwil 1984; Mooney et al. 1974; Pierce 1984; Reader 1975; Stiles 1977). Considerable yearly variations in flowering dates. but unaltered flowering sequences have also been reported from southwestern Spain (Arroyo 1990). In Goegah the shrubby species make up the 'backbone' of the sequence, while therophytes and geophytes close the ranks in seasons when their specific requirements in terms of moisture and temperature conditions are met. This basic pattern remained unchanged, though the vigour of blooming varied greatly between years (see below). Taxonomically related species usually flowered sequentially, with their flowering periods slightly overlapping (e.g. Euphorbia, Hermannia, Ruschia spp.; for further details see Struck 1992).

In the present observations no recurring pattern between the timing and/or amount of precipitation and the timing of flowering in single species or the timing of the blooming season in general were detected, though the vigour of flowering appeared to be stimulated by single rainfall events in single cases (see below).

Moreover, the present data do not indicate that flowering of the therophytes was stimulated by drought. This is in contrast to a view widely accepted for desert annuals (Fox 1990a, b; Rathcke \& Lacey 1985). Yet, recent experimental and field demographic studies (Aronson ef al. 1992: Fox 1989. 1990b; Van Rooyen et al. 1991) indicate that water stress had little or no effect on the induction of flowering.

Conversely, a correlation was found between the autumnal drop in temperatures and the onset of the blooming season: as mentioned above, mean monthly temperatures dropped considerably during March in 1985, but only during April in both of the subsequent years (Table 3). The blooming season started about three months later in each year, namely in early July in 1985 and about early August in both of the subsequent years. It should be noted that the amount and distribution of rainfall during autumn differed notably between the years (Figure 1). The autumnal drop in temperature corresponds to the beginning of the winter rainy season and presumably marks the onset of the growing period for the plants (Van Rooyen of al. 1979).
With regard to the weekly temperatures (or mean temperatures of 7-day-intervals not corresponding to calendar weeks) during autumn (Figure 1), the first cool interval occurred in mid-March in 1985, during the second week of April in 1986, and about the end of April in 1987 (with 5.0, 5.9, and $3.1^{\circ} \mathrm{C}$ below the means of the respective months). These temperature events shifted for about 25 days between 1985 and 1986 and for about 10 days between 1986 and 1987.

This situation is reflected in the yearly shift of flowering dates of selected perennial species (shift 1985/86: about 3 weeks, 1986/87: 4 to 7 days, see Table 5). Though the data show a high degree of variation, the differences appeared to be significant. In contrast, the average shift in flowering dates for selected annuals was 14 and 7 days, respectively. Yet, due to the generally low proportion of annuals in the plots, particularly during drier blooming seasons, the results remain ambiguous (Table 5). However, the lesser yearly shift of flowering dates of annuals may also indicate other influences, e.g. a delay of flowering by low temperatures during the winter period (Van Rooyen et al. 1979). Low temperatures have been shown to lengthen the time between flower initiation and anthesis in therophytes (Van Rooyen et al. 1991). One could expect such an effect for 1985 and 1987 when the cool winter period overlapped with the onset of the blooming period, i.e. when most annuals started to flower. Given this, the differences in flowering dates should be less between $1985 / 86$, but more between 1986/87 compared to the perennials. This is what Table 5 indicates. However, the possibility that this is merely coincidence, cannot be ruled out.

In some species flowering dates differed conspicuously in various places of the study area (c.g. up to a month in Ruschia robusta). Similar observations have also been reported from other arid regions (e.g. Tumer \& Randall 1987 and references cited therein). Whether these differences reflect small-scale variations in soil conditions or intra-specific genetic variability, is not known.

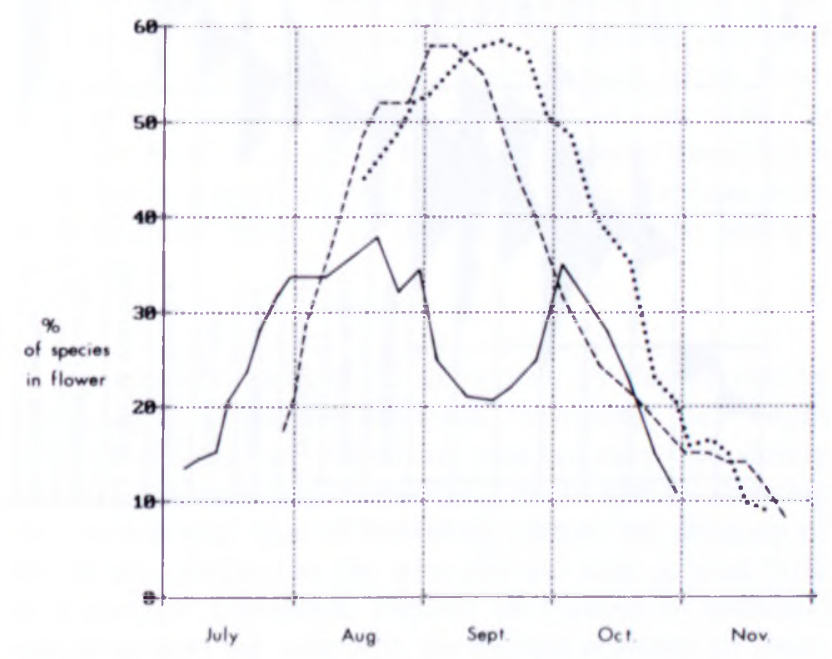

HGiURL 2. Percentage of species llowering simultancously (cumulat live for all plots. $1(00 \%=112$ species $)$. Solid line $=1985 ;$ stippled line $=1986 ;$ dolted line $=1987$. 


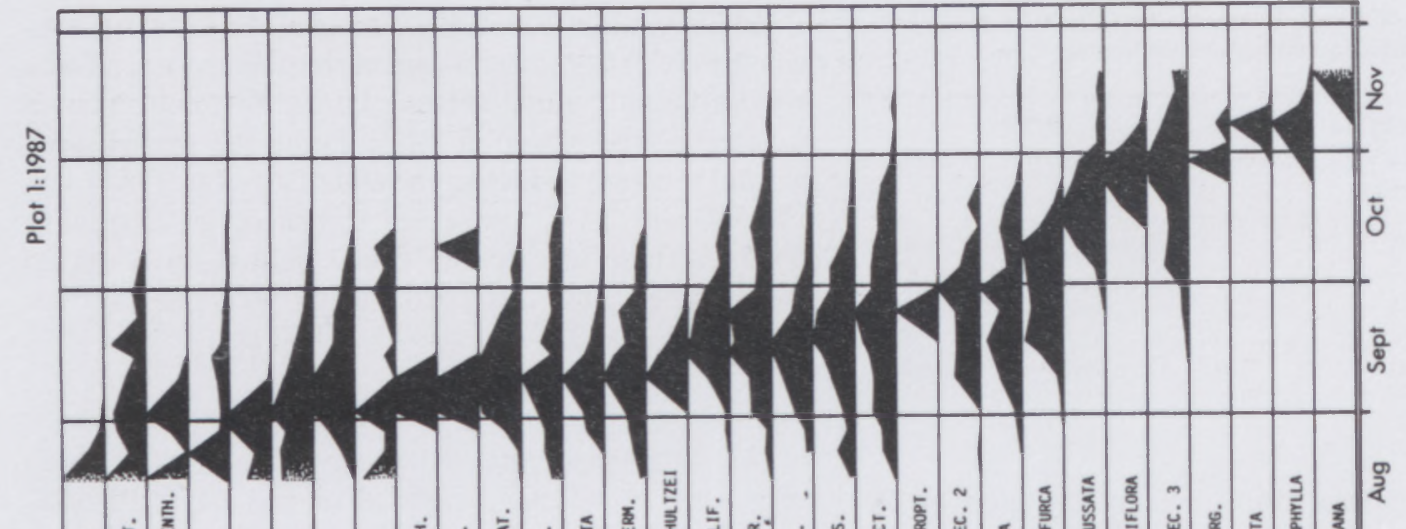

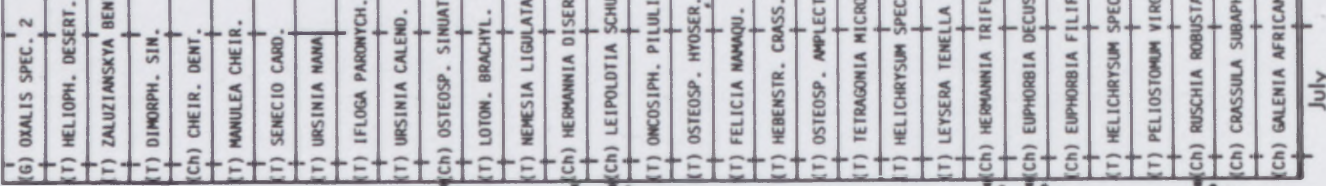

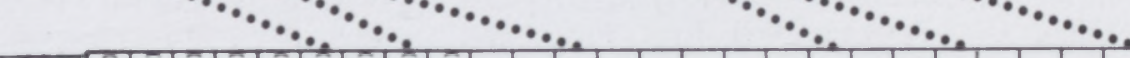

PT:

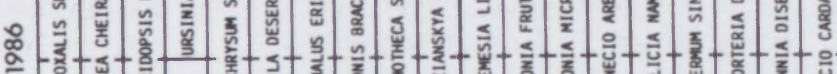

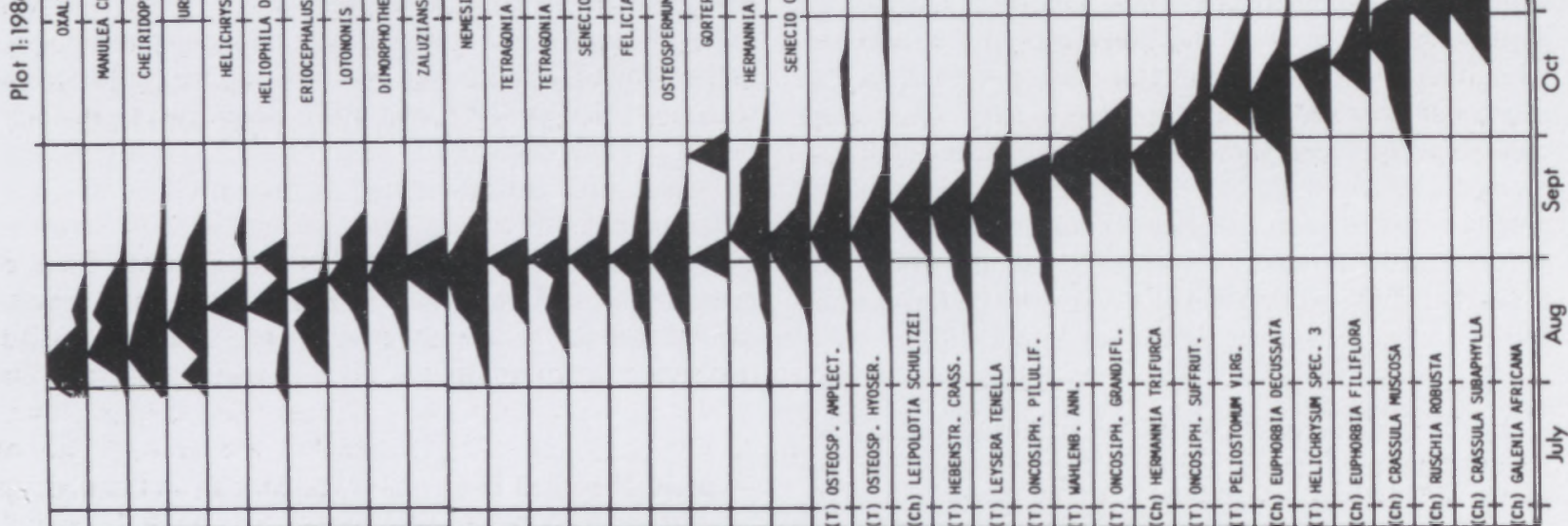
:

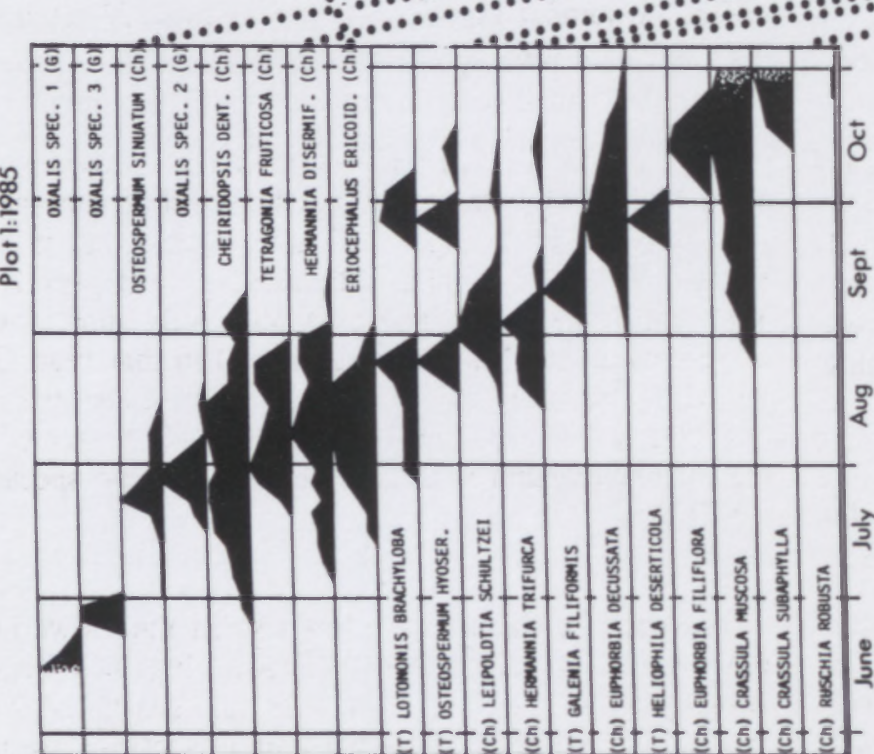

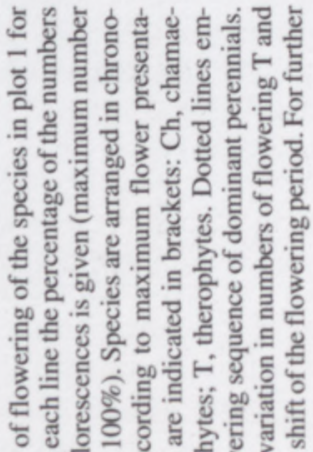

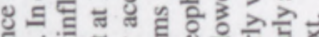

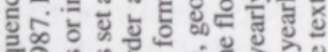

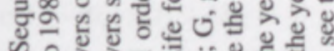

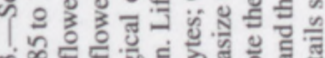
列 
TABIE. 5.-Yearly differences between dates of initial tlowering and dates of peak bloom for selected species. Species poorly represented in the study sites, including all geophytes, were omitted

\begin{tabular}{|c|c|c|c|c|c|c|c|c|c|}
\hline & \multicolumn{4}{|c|}{$1985 / 86$} & \multicolumn{4}{|c|}{$1986 / 87$} & \multirow[b]{2}{*}{$U$} \\
\hline & $\mathrm{n}$ & $x$ & s & V & $\mathrm{n}$ & $\mathbf{x}$ & s & V & \\
\hline \multicolumn{10}{|c|}{ Shift of onset of thowering (in days) } \\
\hline Perennials & 21 & 21.0 & 11.4 & 54.5 & 15 & 3.9 & 7.3 & 187.4 & $P<0.001$ \\
\hline Annuals & 21 & 14.0 & 8.4 & 60.3 & 12 & 7.1 & 14.5 & 131.7 & $P<0.1$ \\
\hline All & 42 & 17.5 & 9.8 & 56.1 & 27 & 12.3 & 9.1 & 73.8 & $P<0.001$ \\
\hline \multicolumn{10}{|c|}{ Shift of peak bloom (in days) } \\
\hline Perennials & 21 & 17.3 & 10.5 & 60.7 & 19 & 7.0 & 9.4 & 133.7 & $P<0.01$ \\
\hline Annuals & 23 & 9.6 & 9.8 & 102.4 & 25 & 4.4 & 8.1 & 183.7 & $P<0.4$ \\
\hline All & 44 & 13.3 & 10.5 & 78.9 & 44 & 12.5 & 8.7 & 69.5 & $P<0.00) 1$ \\
\hline
\end{tabular}

$\mathrm{n}$, sample size; $\mathrm{x}$, mean; s, standard deviation; $\mathrm{V}$, coefficients of variation, $U$, significance after Mann-Whitney $U$ test.

Some of the species under present study were reported to flower one to two months earlier (in 1974, Van Rooyen et al. 1979) or later (in 1981, Le Roux et al. 1989) than observed during the present survey. Nevertheless, the sequence of flowering of the species involved generally matches the present results. Unfortunately, a further comparison is not possible, because the authors collected phenological data in a notably larger area, notwithstanding the small-scale variations of flowering dates. Besides, relevant weather data are lacking for the above-mentioned years.

\section{Numbers of flowers and duration of flowering}

The great majority of the observed species produce large numbers of flowers over a time span of several weeks ("cornucopia", Gentry 1974). In these species the maximum numbers of flowers (or inflorescences, if regarded as the functional unit of visitor attraction or pollination) offered simultaneously, varied from a few thousand to tens of thousands (up to 40000 per $100 \mathrm{~m}^{2}$ in Galenia sarcophylla [Aizoaceae] on plot 6 in 1986).

Conversely, all observed geophytes as well as some chamaephytes and therophytes produced but a few flowers per day over a period of several weeks or more ("steady state', Gentry 1974). Of these the perennial climber Microloma sagittatum (Asclepiadaceae) showed the longest flowering period (120 days). A transitional phenological pattern was shown by some species which produced moderate numbers of flowers over an extensive period (e.g. the succulent shrublet Crassula muscosa subsp. muscosa flowering more than 70 days, the therophytic $O s$ teospermum hyoseroides and $O$. amplectens flowering for 95 days).

As already mentioned, blooming of the therophytes was generally rather poor in 1985, but was markedly better in 1986 and 1987. The shrubby species responded rather differently to seasonal moisture availability: generally. non-succulent shrubs showed the highest production of flowers in the moist years 1986 (most Asteraceae) and 1987 (Lebeckia sericea [Fabaceae]), whereas succulents (most Mesembryanthemaceae, Euphorbia spp.) flowered most prolifically in the comparatively dry season of 1985.
Beside the seasonal moisture availability, single rainfall events appeared to stimulate the vigour of flowering in certain cases. An example is the good rain in early September 1985, which ended a short drought period (Figure 1). After that shower, several therophytes and chamaephytes produced a further minor bloom (Figure 3). Given a causal relationship between these incidents, the species did, nevertheless, not respond to similar rain events (in terms of amount and timing of precipitation) in the subsequent years.

Furthermore, 'small rainfall events' (sensu Sala \& Lauenroth 1982) seemed to stimulate flowering in therophytes: several species in plot 6 (e.g. Senecio arenarius, Leysera tenella) showed a slight, though remarkable increase in the numbers of flowers after sparse rains (below $5 \mathrm{~mm}$ ) occurring during September and the beginning of October 1986 and 1987 . This is in contrast to the findings of various authors (for references see Sala \& Lauenroth 1982) who only regard rain events of at least 8-10 mm ('effective rainfall event' sensu Noy-Meir 1973) as ecologically significant.

The duration of flowering of most taxa ranged from 10 to 80 days. Only the geophytes showed short flowering periods of 20 to 30 days in all three years. Due to the adverse climatic conditions during the growth period of 1985, most therophytes had a comparatively short flowering period (and low flower numbers) in that year. On the other hand, duration of flowering of most therophytes was clearly longer in 1987 than in 1986 (the year with the maximum number of flowering therophytic species. see Table 4).

No specific pattern of skewness in the flowering phenologies could be detected: flowering may begin abruptly and then tail off in one year but may start slowly and end more quickly in another year. In species showing the 'cornucopia' type of flowering pattern the duration of full bloom (defined as the time interval with at least $50 \%$ of a species maximum number of flowers in anthesis) was longest in the year with the highest numbers of flowers and shortest in the year with the lowest numbers of flowers, i.e. a lower flower production was not compensated for by an extended duration of flowering. 


\section{CONCLUSIONS}

A high degree of phenological variation on the species level, and to a lesser extent between populations, is an outstanding feature of the plant community studied. The present observations revealed that the timing of flowering and the vigour of blooming varied independently within the species under study. Conversely, the flowering sequence of given species remained largely unaltered during the years.

Regarding the possible impact of climatic variables, it is inferred that the timing of flowering is indirectly determined by the first considerable drop in air temperatures in autumn and/or by the increase of temperatures in the beginning of spring. In contrast, species composition and number of individuals of therophytes and geophytes in flower are greatly affected by the pattern and amount of seasonal precipitation. The same applies to the number of blossoms produced. Due to fluctuations in seasonal rainfall the vigour of a species' blooming may be promoted in one year and retarded in another. Yet, potential phenological responses seem also to be related to morphological and physiological constrains: e.g. non-succulent shrubs produced the greatest number of flowers in moister years, whereas succulents flowered most prolifically in a dry year.

\section{ACKNOWLEDGEMENTS}

This paper is based on a dissertation submitted in partial fulfilment of the requirements of the Dr rer. nat. at the University of Hamburg (Germany). I am indebted to my supervisor, Prof. Dr H.-D. Ihlenfeldt for his encouragement and constant support. I would like to express my thanks to the directors of the Department of Nature and Environmental Conservation in Cape Town and Jonkershoek for permission to work in the Goegap Nature Reserve and the Officers in Charge for logistical support during my stays. For identifications of plant specimens I appreciate the assistance of Dr V. Bittrich, Dr N. Jürgens, A. le Roux, and Dr K. Steiner. Special thanks are due to A. and G. Cloete, C. Eardley, Dr S.K. Gess, Dr F.W. Gess, E. van Jaarsveld, A. le Roux and Dr V. Whitehead for their generous support during my stays in South Africa. Furthermore, I would like to thank Drs M. Gerbaulet, S.K Gess, F.W. Gess, and unknown referees for comments on drafts of the manuscript. E. van Jaarsveld and E. du Plessis provided the Afrikaans version of the abstract. The work was funded in part by the Deutsche Forschungs- gemeinschaft and by the Akademisches Auslandsamt of the University of Hamburg, for which I am very grateful.

\section{REFERENCES}

ACOCKS. J.P.H. 1988. Veld Types of South Africa, 3rd edn. Memoirs of the Botanical Suney of South Africa No. 57.

ARONSON. J., KIGEL. J., SHMIDA. A. \& KLEIN, J. 1992. Adaptive phenology of desert and mediterranean populations of annual plants grown with and without water stress. Oecologia 89: 17-26.

ARROYO, J. 1990. Spatial variation of flowering phenology in the mediterranean shrublands of southern Spain. Israel Joumal of Botany 39: 249-262.

BAKER. G.A., RUNDEL. P.W. \& PARSONS. D.J. 1982. Comparative phenology and growth in three chaparral shrubs. Botanical Gazette 143: 94-100.

BEATLEY, J.C. 1974. Phenological events and their environmental trig gers in Mojave Desert ecosystems. Ecology 55: 856-863.

FAEGRI. K. \& VAN DER PIJL, L. 1979. The principles of pollination biology, 3 rd edn. Pergamon Press, Oxford.
FOX. G.A. 1989. Consequences of flowering-time variation in a desert annual: adaptation and history. Ecology 70: 1294-1306.

FOX, G.A. 1990). Drought and the evolution of flowering time in desert annuals. American Joumal of Botany 77: 1508-1518.

FOX, G.A. 1990b. Components of flowering time variation in a desert annual. Evolution 44: 1404-1423.

GENTRY, A.H. 1974. Co-evolutionary patterns in Central American Bignoniaceae. Annals of the Missouri Botanical Garden 61: 728 759

GIBBS RUSSELL. G.E., REID, C., VAN ROOY, J. \& SMOOK. L. 1985. List of species of southern African plants, 2nd edn, part I. Memoirs of the Botanical Suney of South Africa No. 51.

GIBBS RUSSELL. G.E., WELMAN. W.G.. RETIEF. E.. IMMELMAN, K.L., GERMISHUIZEN, G., PIENAAR, B.J., VAN WYK, M. \& NICHOLAS, A. 1987. List of species of southern African plants, 2nd edn, part 2. Memoirs of the Botanical Survey of South Africa No 56.

HEINRICH, B. 1976. Flowering phenologies: bog, woodland, and disturbed habitats. Ecology' 57: 890-899.

HEITHAUS, E.R. 1974. The role of plant pollinator interaction in determining community structure. Annals of the Missouri Botanical Garden 61: 675-691

HOCKING. B. 1968. Insect-flower associations in the high Arctic with special reference to nectar. Oikos 19:359-388

HOFFMAN, M.T. \& COWLING, R.M. 1987. Plant physiognomy, phenology and demography. In R.M. Cowling \& P.W. Roux, The Karoo Biome: a preliminan synthesis. Part 2-iegetation and histon: South African National Scientific Programmes Report No. 142: 1-34

KRATOCHWIL, A. 1984. Pflanzengesellschaften und BlütenbesucherGemeinschaften: biozönologische Untersuchungen in einem nicht mehr bewirtschafteten Halbtrockenrasen (Mesobrometum) im Kajserstuhl (Südwestdeutschland). Phytocoenologia 11: 455669.

LE ROUX. A. 1984. 'n Fitososiologiese studie van die Hester MalanNatuurresencat. M.Sc. thesis, University of Pretoria.

LE ROUX, A., PERRY. P. \& KYRIACOU, X. 1989. South Africa. In G. Orshan. Plant phenomorphological studies in mediterranean sype ecosystems. Kluwer Academic Publishers, Dordrecht.

MOONEY, H.A.. PARSONS, D.J. \& KUMMEROW, J. 1974. Plant development in mediterranean climates. In H. Licth, Phenology and seasonality modeling. Ecological Studies 8: 255-268. Springer Verlag, New York.

NOY-MEIR. I. 1973. Desert ecosystems: environment and producers. Annual Review of Ecology and Systematics 4: 25-51

ORSHAN G FLORET Ch LE FLOC ${ }^{*} H$ E LE ROUX A MONTENEGRO, G. \& ROMANE, F. 1989. General synthesis. In G. Orshan. Plant phenomorphological studies in mediterranean type ecosistems: 389-399. Kluwer Academic Publishers, Dordrecht.

PIERCE. S.M. 1984. A synthesis of plant phenology in the Fynbos Biome. South African National Scientific Programmes Report No. 88. Pretoria.

RATHCKE, B. \& LACEY, E.P. 1985. Phenological patterns of terrestrial plants. Annual Review of Ecology and Systematics 16: 179-214.

READER, R.J. 1975. Competitive relationships of some bog ericads for major insect pollinators. Canadian Joumal of Botany 53: 130) 1305 .

RLTHERFORD, M.C. \& WESTFALI. R.H. 1986. Biomes of southern Africa an objective categorization. Memoirs of the Botanical Suriey of South Africa No. 54

SALA, O.E. \& LAUENROTH. W.K. 1982. Small rainfall events: an ecological role in semi-arid regions. (Decologia (Berl.) 53: 301304

SOLBRIG, O.T. \& YANG, T.W. 1977. Strategies in relation to timing of blooming and fruiting. In G.H. Orians \& O.T. Solbrig, Comvergent evolution in wam deserts. US/IBP Synthesis Series 3. 83-90.

STILES, F.G. 1977. Ecology, flowering phenology, and humming bird pollination of some Costa Rican Heliconic. Ecology 56: 285-3()2.

STRLCK. M. 1992. Pollination ecology in the arid winter rainfall region of southern Africa: a case study. Mitteilungen aus dem Institut fiir Allgemeine Botunik Hamburg 24: 61-90)

TURNER. F.B. \& RANDALL. D.C. 1987. The phenology of desert shrubs in southern Nevada. Journal of Arid Environments 13: $119-128$

VAN ROOYEN. M.W., THERON, G.K. \& GROBBELAAR, N. 1979. Phenology of the vegetation in the Hester Malan Nature Rexerve in the Namaqualand Broken Veld: I General obervations. Jour. nal of South A frican Botany 45: 279-293.

VAN ROOYEN, M.W., GROBBELAAR. N.. THERON. G.K \& VAN ROOYEN, N. 1991. The ephemerals of Namaqualand: effects of photoperiod, temperature and moisture stress on development and tlowering of three species. Journal of Arid Emironments 20: 15-29. 


\section{APPENDIX}

Habilat, species compesition, percentage of plant cover and flowering phenology of the permanent plots. Where species flowered twice during a flowering season, number of days of flowering (fourth column) are given separated by " + ". ' + ' put before the number of days indicates that flowering started before an observation period, " + " put behind means that flowering continued after an observation period. Floral units counted (sixth column) were single flowers unless slated otherwise. Names of plant communities follow Ie Roux (1984).

Plot 1. Ruschia robusta-Eriocepholus ericoides Community facies 1: open dwarf-scrub with low proportion of therophytes on NE slope, 5\% inclination, al SE side of Carolusberg

\begin{tabular}{|c|c|c|c|c|c|c|c|c|c|c|c|}
\hline \multirow[t]{2}{*}{ Taxon } & \multirow[t]{2}{*}{$\begin{array}{l}\text { life } \\
\text { form }\end{array}$} & \multicolumn{3}{|c|}{$\begin{array}{l}\text { Cover [\%] } \\
\text { at anthesis }\end{array}$} & \multicolumn{3}{|c|}{$\begin{array}{l}\text { Duration of flowering } \\
\text { [days] }\end{array}$} & \multicolumn{3}{|c|}{$\begin{array}{l}\text { Maximum number of } \\
\text { flowers }\end{array}$} & \multirow[t]{2}{*}{$\begin{array}{l}\text { Floral } \\
\text { unit }\end{array}$} \\
\hline & & 1985 & 1986 & 1987 & 1985 & 1986 & 1987 & 1985 & 1986 & 1987 & \\
\hline Leipoldsia schultzei & $\mathrm{Ch}$ & 3 & 3 & 3 & 70 & 48 & 43 & 7000 & 5000 & 540 & \\
\hline Osteospermum sinuatiem & $\mathrm{Ch}$ & 2 & 2 & 2 & 45 & 58 & +68 & 12 & $6(x)$ & 380 & $\mathrm{Ca}$ \\
\hline Cheiridopsis denticulata & $\mathrm{Ch}$ & 1.5 & 1.5 & 1.5 & $77+10$ & +56 & 29 & 87 & 86 & 16 & \\
\hline Galenia africuna & NP & 1 & 1 & 1 & $?$ & $18+$ & $12+$ & $?$ & $?$ & $?$ & \\
\hline Ruschia robusta & NP & 1 & 1 & 1 & $6+$ & 24 & 11 & $?$ & $7(x)$ & 170 & \\
\hline Eriocephalus ericoides & NP & 1 & 1 & 1 & 50 & 29 & - & 150 & $5(x)$ & - & $\operatorname{lnf}$ \\
\hline Euphorbia decussata & $\mathrm{Ch}$ & 1 & 1 & 1 & $61+$ & $72+$ & $6.3+$ & 2660 & 1798 & 16.34 & Cy \\
\hline Hermunnia trifurca & $\mathrm{Ch}$ & 1 & 1 & 1 & $60+21$ & 42 & 72 & 70 & 650 & 199 & \\
\hline Hermannia disermifolia & $\mathrm{Ch}$ & 0.5 & 0.5 & 0.5 & 6()$+6$ & +75 & +68 & 8 & 105 & 93 & \\
\hline Tetragoniaf fruticosa & $\mathrm{Ch}$ & + & + & + & 38 & 18 & $?$ & 40 & 95 & $?$ & $\operatorname{Inf}$ \\
\hline Crassula muscosa var. muscosa & $\mathrm{Ch}$ & + & + & + & $61+$ & 44 & - & 64 & 17 & - & Inf \\
\hline Crassuala subaphwlla var. subaphylla & $\mathrm{Ch}$ & + & + & + & $12+$ & $37+$ & $22+$ & $?$ & 105 & $\varphi()$ & \\
\hline Euphorbia filiflora & $\mathrm{Ch}$ & + & + & + & 27 & 28 & 33 & 19 & 39 & 33 & $\mathrm{Cy}$ \\
\hline Heliophila deserricola & $\mathrm{T}$ & + & 0.3 & + & 12 & +56 & +63 & 42 & 513 & $?$ & \\
\hline Lotononis brachyloba & $\mathbf{T}$ & $r$ & + & + & $36+16$ & 29 & +83 & 6 & 5 & 70 & \\
\hline Osteospermum hwoseroides & $\mathbf{T}$ & $r$ & + & + & $15+6$ & 83 & 95 & 3 & 48 & 132 & $\mathrm{Ca}$ \\
\hline Galenia filiformis & $\mathbf{T}$ & $r$ & - & - & 22 & - & - & 30 & - & - & Inf \\
\hline Seneciol cardaminifolius & $\mathbf{T}$ & - & 0.1 & + & - & 75 & 58 & - & 350 & 65 & $\mathrm{Ca}$ \\
\hline Dimorphotheca sinuated & $\mathbf{T}$ & - & + & + & - & 38 & +78 & - & 20 & 84 & $\mathrm{Ca}$ \\
\hline Felicia namaquana & $\mathbf{T}$ & - & + & + & - & 42 & 77 & - & 57 & 58 & $\mathrm{Ca}$ \\
\hline Hebenstretia robusta & $\mathrm{T}$ & - & + & + & - & 56 & +78 & - & 75 & 41 & $\operatorname{lnf}$ \\
\hline Manulea cheiranthus & $\mathrm{T}$ & - & + & + & - & +56 & +68 & - & $6(x)$ & $?$ & Inf \\
\hline Osteospermum amplectens & $\mathrm{T}$ & - & + & + & - & 88 & 95 & - & 43 & 100 & $\mathrm{Ca}$ \\
\hline Helichnsum micnopoides & $\mathbf{T}$ & - & + & $r$ & - & 25 & 62 & - & 20 & 22 & Inf \\
\hline Nemesia ligulasa & $\mathrm{T}$ & - & + & $r$ & - & $6(x)$ & 57 & - & 92 & 19 & \\
\hline Helichrysum leomomyx & $\mathrm{T}$ & - & $r$ & + & - & 12 & $66+$ & - & 9 & 323 & Inf \\
\hline Ursinias nana & $\mathrm{T}$ & - & $r$ & + & - & 45 & +58 & - & 5 & 4 & $\mathrm{Ca}$ \\
\hline Zaluzianskva benthamiana & $\mathbf{T}$ & - & $r$ & + & - & 11 & +29 & - & 1 & 5 & Inf \\
\hline Leysers tenella & $\mathbf{T}$ & - & $\mathrm{r}$ & $r$ & - & 32 & $84+$ & - & 74 & $1(x)$ & $\mathrm{Ca}$ \\
\hline Oncosiphom piluliferum & $\mathbf{T}$ & - & r & r & - & 31 & 62 & - & 12 & 30 & $\mathrm{Ca}$ \\
\hline Oncosiphom suffrunicosum & $\mathbf{T}$ & - & r & $r$ & - & 49 & 19 & - & 1.3 & 2 & $\operatorname{lnf}$ \\
\hline Peliostomum virgatum & $\mathbf{T}$ & - & $r$ & $r$ & - & 20 & 1.3 & - & 5 & 3 & \\
\hline Tetragonia microptera & $\mathbf{T}$ & - & $r$ & $\mathbf{r}$ & - & 29 & 5 & - & 15 & 5 & Inf \\
\hline Wahlenhergia annularis & $\mathbf{T}$ & - & $r$ & $\mathbf{r}$ & - & $19+10$ & 39 & - & 7 & 4 & \\
\hline Gasania lichtensteinii & $\mathrm{T}$ & - & $r$ & - & - & $6+6$ & - & - & 1 & - & $\mathrm{Ca}$ \\
\hline Oncosiphon grandiflorum & $\mathbf{T}$ & - & $r$ & - & - & 18 & - & - & 1 & - & $\mathrm{Ca}$ \\
\hline Senecio arenarius & $\mathbf{T}$ & - & $r$ & - & - & 18 & - & - & 4 & - & $\mathrm{Ca}$ \\
\hline Ifloga paronvchiovides & $\mathbf{T}$ & - & - & $\mathbf{r}$ & - & - & 14 & - & - & 5 & $\operatorname{lnf}$ \\
\hline Ursinia calenduliffora & $\mathbf{T}$ & - & - & $\mathbf{r}$ & - & - & $14+4$ & - & - & 1 & Ca \\
\hline Oralis sp. 2 (Siruck 37) & $G$ & + & + & + & $19+5$ & +35 & +24 & 7 & 52 & $?$ & \\
\hline Oxalis sp I (Siruck 36) & $G$ & + & - & - & +11 & $?$ & $?$ & 10 & $?$ & $?$ & \\
\hline Oralis sp. 3 (Siruck 38) & G & $r$ & - & - & 6 & $?$ & $?$ & 1 & $?$ & $?$ & \\
\hline Chlorophyum crassinerve & G & - & $\mathbf{r}$ & - & - & - & - & - & - & - & \\
\hline Total cover $|\not|$ & & 15 & 16 & 16 & & & & & & & \\
\hline
\end{tabular}

Ch. chamacphytes; NP, nanophanerophytes; T, therophytes: G, geophytes; Ca, capitula; Cy, cyathia; Inf, inflorescences or flower aggregates. 
Plot 2. Didelta spinosa-Ruschia cymosa Community: moderately dense scrub with low proportion of therophytes on SSE slope, $20 \%$ inclination at SE side of Carolusberg

\begin{tabular}{|c|c|c|c|c|c|c|c|c|c|c|c|}
\hline \multirow[t]{2}{*}{ Taxon } & \multirow[t]{2}{*}{$\begin{array}{l}\text { Life } \\
\text { form }\end{array}$} & \multicolumn{3}{|c|}{$\begin{array}{l}\text { Cover }[\%] \\
\text { at anthesis }\end{array}$} & \multicolumn{3}{|c|}{$\begin{array}{l}\text { Duration of flowering } \\
\text { [days] }\end{array}$} & \multicolumn{3}{|c|}{$\begin{array}{l}\text { Maximum number of } \\
\text { flowers }\end{array}$} & \multirow[t]{2}{*}{$\begin{array}{c}\text { Floral } \\
\text { unit }\end{array}$} \\
\hline & & 1985 & 1986 & 1987 & 1985 & 1986 & 1987 & 1985 & 1986 & 1987 & \\
\hline Ruschia cymosa & $\mathrm{Ch}$ & 5 & 5 & 5 & 43 & 26 & 36 & 3900 & 1000 & 1183 & \\
\hline Berkheya fruticosa & $\mathrm{NP}$ & 3.5 & 3.5 & 3.5 & 61 & 56 & 76 & 41 & 1200 & 560 & $\mathrm{Ca}$ \\
\hline Eriocephalus ericoides & NP & 1.5 & 1.5 & 1.5 & 57 & 36 & - & 1000 & 1700 & - & Inf \\
\hline Othonna furcata & NP & 1.5 & 1.5 & 1.5 & \multicolumn{3}{|c|}{ (flowering in March) } & $?$ & $?$ & $?$ & \\
\hline Euphorbia mauritanica & $\mathrm{Ch} / \mathrm{NP}$ & 1 & 1 & 1 & 87 & 36 & +49 & 1000 & 650 & 85 & Inf \\
\hline Pteronia incana & $\mathrm{Ch}$ & 1 & 1 & 1 & 44 & 26 & 44 & 1100 & 340 & 75 & $\mathrm{Ca}$ \\
\hline Thesium lineatum & $\mathrm{Ch} / \mathrm{NP}$ & 1 & 1 & 1 & 45 & 44 & 43 & 850 & 1700 & 180 & Inf \\
\hline Didelta spinosa & NP & 0.5 & 0.5 & 0.5 & 41 & 48 & 34 & 33 & 159 & 38 & $\mathrm{Ca}$ \\
\hline Hirpicium alienatum & $\mathrm{Ch}$ & 0.5 & 0.5 & 0.5 & 70 & 72 & 62 & 95 & 303 & 65 & $\mathrm{Ca}$ \\
\hline Othonna arbuscula & $\mathrm{Ch} / \mathrm{NP}$ & 0.5 & 0.5 & 0.5 & 50 & +40 & +44 & 120 & 264 & $?$ & $\mathrm{Ca}$ \\
\hline Galenia africana & NP & 0.4 & 0.4 & 0.4 & $?$ & $13+$ & $4+$ & $?$ & 120 & $?$ & Inf \\
\hline Zygophyllum meyeri & $\mathrm{Ch} / \mathrm{NP}$ & 0.4 & 0.4 & 0.4 & 7 & 38 & 43 & 1 & 70 & 15 & \\
\hline Osteospermum grandiflorum & $\mathrm{Ch}$ & 0.3 & 0.3 & 0.3 & - & - & - & - & - & - & \\
\hline Osteospermum sinuatum & $\mathrm{Ch}$ & 0.3 & 0.3 & 0.3 & $34+10$ & 60 & 57 & 12 & 225 & 70 & $\mathrm{Ca}$ \\
\hline Cheiridopsis denticulata & $\mathrm{Ch}$ & + & + & + & 22 & 22 & - & 6 & 3 & - & \\
\hline Felicia brevifolia & $\mathrm{Ch}$ & + & + & + & - & 18 & $4+3$ & - & 24 & 3 & $\mathrm{Ca}$ \\
\hline Leipoldtia schultzei & $\mathrm{Ch}$ & + & + & + & 27 & 16 & - & 110 & 130 & - & \\
\hline Microloma sagittatum & Ch & + & + & + & 122 & +96 & +83 & 75 & 40 & 17 & Inf \\
\hline Ruschia viridifolia & $\mathrm{Ch}$ & + & + & + & 26 & 26 & - & 40 & 55 & - & \\
\hline Tetragonia fruticosa & $\mathrm{Ch}$ & + & + & + & 35 & 22 & +6 & 250 & 160 & $?$ & Inf \\
\hline Crassula atropupurea var. watermeyeri & $\mathrm{Ch}$ & $r$ & $r$ & r & 26 & 20 & 19 & 23 & 25 & 14 & \\
\hline Crassula subaphylla var. subaphylla & $\mathrm{Ch}$ & $\mathbf{r}$ & + & - & 21 & 24 & - & 26 & 30 & - & Inf \\
\hline Crassula muscosa var. muscosa & $\mathrm{Ch}$ & $r$ & $r$ & $r$ & $61+$ & 59 & $+95+$ & 65 & 66 & 77 & Inf \\
\hline Heliophila comuta & $\mathrm{Ch}$ & $r$ & $r$ & $r$ & - & 13 & 39 & - & 6 & 12 & \\
\hline Tetragonia macroptera & $\mathrm{Ch}$ & r & r & $r$ & 17 & 9 & 15 & 1 & 26 & 5 & Inf \\
\hline Senecio cardaminifolius & $\mathrm{T}$ & $r$ & + & + & $5+5$ & 37 & 57 & 1 & 215 & 110 & $\mathrm{Ca}$ \\
\hline Ursinia calenduliflora & $\mathrm{T}$ & $\mathbf{r}$ & + & + & 12 & 53 & 62 & 2 & 280 & 146 & $\mathrm{Ca}$ \\
\hline Leysera tenella & $\mathrm{T}$ & $r$ & - & $r$ & 21 & - & 49 & 2 & - & 17 & $\mathrm{Ca}$ \\
\hline Heliophila deserticola & $\mathrm{T}$ & - & + & + & - & $5+5+9$ & 60 & - & 54 & 296 & \\
\hline Osteospermum amplectens & $\mathrm{T}$ & - & $\mathbf{r}$ & + & - & 35 & 62 & - & 2 & 24 & $\mathrm{Ca}$ \\
\hline Osteospermum hyoseroides & $\mathrm{T}$ & - & $r$ & + & - & 52 & 62 & - & 7 & 7 & $\mathrm{Ca}$ \\
\hline Oncosiphon suffruticosum & $\mathrm{T}$ & - & $\mathbf{r}$ & $r$ & - & 8 & 9 & - & 3 & 2 & Inf \\
\hline Diascia namaquensis short-spurred form & $\mathrm{T}$ & - & r & $r$ & - & $4+6$ & 8 & - & 3 & 1 & \\
\hline Senecio arenarius & $\mathrm{T}$ & - & $\mathbf{r}$ & - & - & 7 & - & - & 1 & - & $\mathrm{Ca}$ \\
\hline Dimorphotheca sinuata & $\mathrm{T}$ & - & $r$ & - & - & 9 & 10 & - & 1 & 1 & $\mathrm{Ca}$ \\
\hline Nemesia ligulata & $\mathrm{T}$ & - & $r$ & - & - & 16 & - & - & 2 & - & \\
\hline Cleretum papulosum subsp. papulosum & $\mathrm{T}$ & - & - & $\mathbf{r}$ & - & - & $?$ & - & (cleisto & mous) & \\
\hline Galenia fillformis & $\mathrm{T}$ & - & - & r & - & - & 44 & - & - & 8 & $\operatorname{lnf}$ \\
\hline Tetragonia microptera & $\mathrm{T}$ & - & - & $r$ & - & - & 15 & - & - & 6 & $\ln f$ \\
\hline Ursinia nana & $\mathrm{T}$ & - & - & $\mathbf{r}$ & - & - & 43 & - & - & 2 & $\mathrm{Ca}$ \\
\hline Oxalis obtusa & G & + & + & + & 46 & 38 & +49 & 2 & 48 & 65 & \\
\hline Asparagus asparagoides & G & r & $\mathrm{r}$ & - & - & - & - & - & - & - & \\
\hline Lachenalia violacea & G & r & $\mathrm{r}$ & + & 7 & 16 & 30 & 1 & 3 & 2 & Inf \\
\hline Gladiolus orchidiflorus & G & - & - & $r$ & - & - & 20 & - & - & 4 & \\
\hline Trachyandra flexifolia & G & - & - & $r$ & - & - & 3 & - & - & 2 & \\
\hline Total cover $[\%]$ & & 20 & 21 & 21 & & & & & & & \\
\hline
\end{tabular}

Ch, chamaephytes; NP, nanophanerophytes; T, therophytes; G, geophytes; Ca, capitula; Cy, cyathia; Inf, inflorescences or flower aggregates. 
Plot 3. Ruschia robusta-Eriocephalus ericoides Community: open scrub and dwarf-scrub with moderate proportion of therophytes on WSW slope, 6\% inclination, at SE side of Carolusberg

\begin{tabular}{|c|c|c|c|c|c|c|c|c|c|c|c|}
\hline \multirow[t]{2}{*}{ Taxon } & \multirow[t]{2}{*}{$\begin{array}{l}\text { Life } \\
\text { form }\end{array}$} & \multicolumn{3}{|c|}{$\begin{array}{l}\text { Cover } \mid \%] \\
\text { at anthesis }\end{array}$} & \multicolumn{3}{|c|}{$\begin{array}{l}\text { Duration of flowering } \\
\text { [days] }\end{array}$} & \multicolumn{3}{|c|}{$\begin{array}{l}\text { Maximum number of } \\
\text { flowers }\end{array}$} & \multirow[t]{2}{*}{$\begin{array}{l}\text { Floral } \\
\text { unit }\end{array}$} \\
\hline & & 1985 & 1986 & 1987 & 1985 & 1986 & 1987 & 1985 & 1986 & 1987 & \\
\hline Polymisa albiflora & $\mathrm{Ch}$ & 6 & 6 & 6 & $27+$ & 33 & $32+$ & 1600 & 744 & 474 & \\
\hline Lebeckia sericea & NP & 5 & 5 & 5 & 57 & 36 & 62 & 250 & 850 & 1240 & Inf \\
\hline Tetragonia fruticosa & $\mathrm{Ch}$ & 1.3 & 1.3 & 1.3 & 65 & +40 & +39 & $15(x)$ & 2080 & 180 & Inf \\
\hline Ruschia viridifolia & $\mathrm{Ch}$ & 1 & 1 & 1 & 21 & 22 & 14 & 950 & 177 & 130 & \\
\hline Osteospermum grandiflorum & $\mathrm{Ch}$ & 0.5 & 0.5 & 0.5 & $49+17$ & 63 & 73 & 100 & 215 & 210 & $\mathrm{Ca}$ \\
\hline Euphorbia decussata & $\mathrm{Ch}$ & 0.25 & 0.25 & 0.25 & $39+$ & 30 & 56 & 2500 & 270 & 1300 & Cy \\
\hline Hirpicium alienarum & $\mathrm{Ch}$ & + & + & + & 12 & 18 & 30 & 2 & 27 & 12 & $\mathrm{Ca}$ \\
\hline Ursinia calenduliflora & $\mathbf{T}$ & $r$ & 1 & + & $5+5$ & 38 & +68 & 4 & 530 & 500 & $\mathrm{Ca}$ \\
\hline Heliophila deserricola & $\mathbf{T}$ & - & 0.3 & 0.5 & - & 50 & +54 & - & 206 & 600 & \\
\hline Osteospermum amplectens & $\mathbf{T}$ & - & + & + & - & $42+13$ & +63 & $\neg$ & 33 & 67 & $\mathrm{Ca}$ \\
\hline Osteospermum hyoseroides & $\mathbf{T}$ & - & + & + & - & $42+4$ & +63 & - & 40 & 63 & $\mathrm{Ca}$ \\
\hline Senecio cardaminifolius & $\mathbf{T}$ & - & + & $\mathrm{r}$ & - & 38 & 49 & - & 25 & 25 & $\mathrm{Ca}$ \\
\hline Helichnsum micnopoides & $\mathrm{T}$ & - & $\mathbf{r}$ & - & - & $4+7$ & - & - & 10 & - & Inf \\
\hline Ifloga paronychioides & $\mathrm{T}$ & - & r & - & - & 4 & - & - & 2 & - & $\operatorname{lnf}$ \\
\hline Oxalis obrusa & G & + & + & + & 19 & +40 & +16 & 6 & 20 & 19 & \\
\hline Gynandriris setifolia & $\mathrm{G}$ & - & - & $r$ & - & - & $4+5$ & - & - & 2 & \\
\hline Morciea fugax & $\mathrm{G}$ & - & - & $r$ & - & - & 26 & - & - & 2 & \\
\hline Ornithogalum zebrinum & G & - & - & $r$ & - & - & 5 & - & - & 1 & \\
\hline Total cover $[\%]$ & & 15 & 17 & 16 & & & & & & & \\
\hline
\end{tabular}

Ch, chamaephytes; NP. nanophanerophytes; T, therophytes; G, geophytes; Ca, capitula; Cy, cyathia; Inf, inflorescences or flower aggregates.

Plot 4. Ruschics robusta-Eriocephalus ericoides Community: moderately dense scrub and dwarf-scrub with high proportion of therophytes on SE slope. $8 \%$ inclination. at SE side of Carolusberg

\begin{tabular}{|c|c|c|c|c|c|c|c|c|c|c|c|}
\hline \multirow[t]{2}{*}{ Taxon } & \multirow[t]{2}{*}{$\begin{array}{l}\text { Life } \\
\text { form }\end{array}$} & \multicolumn{3}{|c|}{$\begin{array}{l}\text { Cover }[\%] \\
\text { at anthesis }\end{array}$} & \multicolumn{3}{|c|}{$\begin{array}{c}\text { Duration of flowering } \\
\text { [days] }\end{array}$} & \multicolumn{3}{|c|}{$\begin{array}{l}\text { Maximum number of } \\
\text { flowers }\end{array}$} & \multirow[t]{2}{*}{$\begin{array}{c}\text { Floral } \\
\text { unit }\end{array}$} \\
\hline & & 198.5 & 1986 & 1987 & 198.5 & 1986 & 1987 & 1985 & 1986 & 1987 & \\
\hline Lebeckia sericea & NP & 8 & 8 & 8 & 22 & 44 & +58 & 40 & 750 & 1500 & Inf \\
\hline Ruschia elineata & $\mathrm{Ch}$ & 8 & 8 & 8 & 68 & +29 & $?$ & $?$ & $?$ & $?$ & \\
\hline Polymita albiflora & $\mathrm{Ch}$ & 1.3 & 1.3 & 1.3 & $27+$ & 24 & 22 & 600 & 175 & 140 & \\
\hline Hirpicium alienatum & $\mathrm{Ch}$ & 1 & 1 & 1 & $76+$ & 79 & 71 & 38 & 650 & 185 & $\mathrm{Ca}$ \\
\hline Tetragonia fruticosa & $\mathrm{Ch}$ & 1 & 1 & 1 & 67 & +40 & +58 & 1400 & 1420 & $?$ & $\operatorname{lnf}$ \\
\hline Leipoldria schulrzei & $\mathrm{Ch}$ & 0.5 & 0.5 & 0.5 & 54 & 26 & 8 & 1270 & $5(x)$ & 20 & \\
\hline Galenia fruricosa & $\mathrm{Ch}$ & 0.5 & 0.5 & 0.5 & 50 & 34 & 53 & 1500 & 3500 & $11(x)$ & $\operatorname{Inf}$ \\
\hline Eriocephalus africanus & $\mathrm{Ch}$ & + & + & + & - & 29 & - & - & 180 & - & Inf \\
\hline Felicia brevifolia & $\mathrm{Ch}$ & + & + & + & 41 & 36 & +39 & 30 & 122 & 23 & $\mathrm{Ca}$ \\
\hline Galenia africana & NP & + & + & + & $?$ & $9+$ & $4+$ & $?$ & $?$ & $?$ & \\
\hline Osteospermum sinuatum & $\mathrm{Ch}$ & + & + & + & 31 & 45 & 38 & 4 & 23 & 18 & $\mathrm{Ca}$ \\
\hline Ruschia robusfa & $\mathrm{Ch} / \mathrm{NP}$ & + & + & + & - & 13 & $?$ & - & 80 & $?$ & \\
\hline Crassula muscosa var. muscosa & $\mathrm{Ch}$ & $\mathbf{r}$ & $r$ & $r$ & $?$ & $?$ & $?$ & $?$ & $?$ & $?$ & \\
\hline Microloma sagiffatum & $\mathrm{Ch}$ & $r$ & $r$ & r & $?$ & +86 & 95 & $?$ & 34 & 5 & $\operatorname{lnf}$ \\
\hline Ruschia viridifolia & $\mathrm{Ch}$ & $\mathbf{r}$ & $\mathrm{r}$ & $r$ & - & 14 & - & - & 13 & - & \\
\hline Ursinia calenduliftora & $\mathrm{T}$ & $\mathbf{r}$ & 1 & 0.5 & $15+10$ & 56 & +68 & 5 & 315 & 307 & $\mathrm{Ca}$ \\
\hline Leysena tenella & $\mathbf{T}$ & $r$ & + & + & 5 & 19 & 67 & 1 & 56 & 250 & $\mathrm{Ca}$ \\
\hline Osteospermum hyoseroides & $\mathbf{T}$ & $\mathbf{r}$ & + & + & 5 & 22 & 67 & 2 & 11 & 32 & $\mathrm{Ca}$ \\
\hline Heliophila deserricola & $\mathbf{T}$ & - & 0.3 & 1 & - & 56 & +54 & - & 354 & $20(x)$ & \\
\hline Osteospermum amplectens & $\mathrm{T}$ & - & + & 1 & - & $48+14$ & $+95+$ & - & 111 & 303 & $\mathrm{Ca}$ \\
\hline Helichrysum micnopoides & $\mathbf{T}$ & - & + & 0.5 & - & 42 & +73 & - & $7(0)$ & 300 & $\operatorname{lnf}$ \\
\hline Felicia namaquana & $\mathbf{T}$ & - & + & + & - & 55 & +68 & - & 45 & 256 & $\mathrm{Ca}$ \\
\hline Hebenstresia robusta & $\mathrm{T}$ & - & + & + & - & 42 & +49 & - & 56 & 17 & $\operatorname{lnf}$ \\
\hline Senecio cardaminifolius & $\mathrm{T}$ & - & + & + & - & 55 & +68 & - & $10(x)$ & 6.50 & $\mathrm{Ca}$ \\
\hline
\end{tabular}




\begin{tabular}{|c|c|c|c|c|c|c|c|c|c|c|c|}
\hline Ursinia nana & $\mathbf{T}$ & - & + & + & - & 56 & +58 & - & 23 & 33 & $\mathrm{Ca}$ \\
\hline Cleretum papulosum subsp. papulosum & $\mathrm{T}$ & - & + & r & - & 29 & 16 & - & 21 & 5 & \\
\hline Nemesia ligulata & $\mathbf{T}$ & - & + & r & - & 38 & 33 & - & 24 & 5 & \\
\hline Oncosiphon piluliferum & $\mathbf{T}$ & - & + & $r$ & - & 48 & 63 & - & 11 & 6 & Inf \\
\hline Tetragonia microptera & $\mathbf{T}$ & - & + & $r$ & - & 36 & 33 & - & 25 & 23 & Int \\
\hline Oncosiphon suffruticosum & $\mathrm{T}$ & - & $r$ & + & - & 27 & 39 & - & 21 & 32 & $\mathrm{Ca}$ \\
\hline Zaluzianskya benthamiana & $\mathbf{T}$ & - & $\mathrm{r}$ & + & - & $8+5$ & 23 & - & 1 & 10 & $\operatorname{lnt}$ \\
\hline Arctotis fastuosa & $\mathrm{T}$ & - & $\mathrm{r}$ & $r$ & - & 22 & $21+5$ & - & 2 & 1 & $\mathrm{Ca}$ \\
\hline Diascia namaquensis short-spurred form & $\mathrm{T}$ & - & $r$ & r & - & 41 & 17 & - & 33 & 3 & \\
\hline Galenia sarcophylla & $\mathrm{T}$ & - & r & $r$ & - & 27 & - & - & 40 & - & Int \\
\hline Gazania lichtensteinii & $\mathbf{T}$ & - & r & $r$ & - & 26 & $33+5$ & - & 6 & 1 & $\mathrm{Ca}$ \\
\hline Senecio arenarius & $\mathbf{T}$ & - & $r$ & $r$ & - & 31 & 14 & - & 9 & 2 & $\mathrm{Ca}$ \\
\hline Diascia namaquensis long-spurred form & $\mathbf{T}$ & - & r & - & - & 25 & - & - & 5 & - & \\
\hline Diascia runcinata & $\mathrm{T}$ & - & $r$ & - & - & 36 & - & - & 4 & - & \\
\hline Dimorphotheca sinuata & $\mathbf{T}$ & - & $r$ & - & - & 27 & - & - & 3 & - & $\mathrm{Ca}$ \\
\hline Wahlenbergia prostrata & $\mathrm{T}$ & - & $\mathrm{r}$ & - & - & 9 & - & - & 2 & - & \\
\hline Galenia filiformis & $\mathrm{T}$ & - & - & $r$ & - & - & 19 & - & - & 25 & Int \\
\hline Oxalis obrusa & G & + & + & + & 57 & +47 & +29 & 3 & 48 & 81 & \\
\hline Albuca cooperi & G & - & - & $r$ & - & - & 12 & - & - & 1 & \\
\hline Moraea fugax & G & - & - & $r$ & - & - & 5 & - & - & 1 & \\
\hline Trachyandra flexifolia & G & - & - & $r$ & - & - & 7 & - & - & 1 & \\
\hline Total cover [\%] & & 20 & 22 & 25 & & & & & & & \\
\hline
\end{tabular}

Ch. chamaephytes: NP, nanophanerophytes; T, therophytes; G, geophytes; Ca, capitula; Cy, cyathia; Inf, inflorescences or flower aggregates.

Plot 5. Ruschia robusta-Eriocephalus ericoides Community facies 1: open dwarf-scrub with high proportion of therophytes on SSW slope, $6 \%$ inclination, at SE side of Carolusberg

\begin{tabular}{|c|c|c|c|c|c|c|c|c|c|c|c|}
\hline \multirow[t]{2}{*}{ Taxon } & \multirow[t]{2}{*}{$\begin{array}{l}\text { Life } \\
\text { form }\end{array}$} & \multicolumn{3}{|c|}{$\begin{array}{l}\text { Cover }[\%] \\
\text { at anthesis }\end{array}$} & \multicolumn{3}{|c|}{$\begin{array}{l}\text { Duration of flowering } \\
\text { [days] }\end{array}$} & \multicolumn{3}{|c|}{$\begin{array}{l}\text { Maximum number of } \\
\text { flowers }\end{array}$} & \multirow[t]{2}{*}{$\begin{array}{c}\text { Floral } \\
\text { unit }\end{array}$} \\
\hline & & 1985 & 1986 & 1987 & 1985 & 1986 & 1987 & 1985 & 1986 & 1987 & \\
\hline Leipoldtia schultzei & $\mathrm{Ch}$ & 10 & 10 & 10 & 87 & 37 & 33 & $10000)$ & $700(x)$ & 80 & \\
\hline Ruschia robusta & $\mathrm{NP}$ & 4 & 4 & 4 & $12+$ & 28 & $?$ & 8500 & 1800 & $?$ & \\
\hline Osteospermum sinuatum & $\mathrm{Ch}$ & 2 & 2 & 2 & $46+10$ & 49 & 58 & 3 & $4(x)$ & $260)$ & $\mathrm{Ca}$ \\
\hline Euphorbia mauritanica & $\mathrm{Ch} / \mathrm{NP}$ & 1.3 & 1.3 & 1.3 & $116+$ & 66 & 54 & 437 & 1500 & 55 & Inf \\
\hline Euphorbia decussata & $\mathrm{Ch}$ & 1 & 1 & 1 & $66+$ & 59 & 65 & 1650 & 550 & 1055 & $\mathrm{Cy}$ \\
\hline Galenia africana & $\mathrm{NP}$ & 0.8 & 0.8 & 0.8 & ? & $?$ & ? & $?$ & ? & $?$ & \\
\hline Tetragonia fruticosa & $\mathrm{Ch}$ & 0.5 & 0.5 & 0.5 & 67 & 29 & $?$ & 385 & 450 & $?$ & Inf \\
\hline Galenia fruticosa & $\mathrm{Ch}$ & 0.3 & 0.3 & 0.3 & 56 & 42 & 44 & $9(0)$ & 2000 & $15(x)$ & Inf \\
\hline Hirpicium alienatum & $\mathrm{Ch}$ & 0.3 & 0.3 & 0.3 & - & 4) & 29 & - & 45 & 8 & $\mathrm{Ca}$ \\
\hline Cheiridopsis denticulata & $\mathrm{Ch}$ & + & + & + & 55 & 52 & 18 & 13 & 7 & 1 & \\
\hline Hermannia disermifolia & $\mathrm{Ch}$ & + & + & + & $71+10$ & 52 & 57 & 32 & 100 & 120 & \\
\hline Tylecodon wallichii & $\mathrm{Ch}$ & $\mathrm{r}$ & $\mathrm{r}$ & $\mathrm{r}$ & $?$ & $?$ & $?$ & $?$ & ? & ? & \\
\hline Crassula atropurpurea var. watermeyeri & $\mathrm{Ch}$ & $r$ & $r$ & $r$ & 16 & 16 & - & 6 & 1 & - & \\
\hline Microloma sagittatum & $\mathrm{Ch}$ & r & $\mathrm{r}$ & $\mathrm{r}$ & - & +86 & $80+$ & - & 47 & 7 & $\operatorname{lnf}$ \\
\hline Aptosimum indivisum & $\mathrm{T}$ & + & + & + & 6 & 72 & $54+5$ & 1 & $19)$ & 73 & \\
\hline Osteospermum hyoseroides & $\mathrm{T}$ & r & + & 0.5 & 5 & 100 & +83 & 1 & 91 & 240) & $\mathrm{Ca}$ \\
\hline Hebenstretia robusta & $\mathrm{T}$ & $r$ & + & + & 10 & 48 & +68 & 5 & 289 & 210 & Inf \\
\hline Galenia filiformis & $\mathrm{T}$ & $r$ & $r$ & $r$ & 12 & 9 & 4 & 20 & 10 & 93 & $\operatorname{Inf}$ \\
\hline Leysera tenella & $\mathrm{T}$ & $r$ & $r$ & $\mathrm{r}$ & 11 & $16+30$ & 72 & 2 & 3 & 58 & $\mathrm{Ca}$ \\
\hline Senecio cardaminifolius & $\mathbf{T}$ & - & 1 & + & - & 63 & +68 & - & $8(x)$ & $7(0)$ & $\mathrm{Ca}$ \\
\hline Heliophila cf. lactea & $T$ & - & 0.5 & 0.5 & - & 76 & +63 & - & $3(x)$ & 435 & \\
\hline Helichnsum micropoides & $\mathbf{T}$ & - & 0.3 & 1.5 & - & 5) & +63 & - & $4(x)$ & 750 & Inf \\
\hline Zaluzianskya benthamiana & $\mathbf{T}$ & - & + & 0.5 & - & 4 & +54 & - & 93 & 116 & Inf \\
\hline Dimorphotheca sinuata & $\mathrm{T}$ & - & + & + & - & 29 & +73 & - & 7 & 16 & $\mathrm{Ca}$ \\
\hline Helichnysum leontonyx & $\mathrm{T}$ & - & + & + & - & 50 & $71+$ & - & 175 & 1120 & Inf \\
\hline Heliophila deserticola & $\mathrm{T}$ & - & + & + & - & $23+20$ & 63 & - & 34 & 89 & \\
\hline Osteospermum amplectens & $\mathrm{T}$ & - & + & + & - & 90 & +95 & - & 44 & 14) & $\mathrm{Ca}$ \\
\hline
\end{tabular}


Ursinia calenduliflora

Felicia namaquana

Arctotis fastuosa

Peliostomum virgatum

Diascia namaquensis short-spurred form

Lotononis brachyloha

Oncosiphon grandiflorum

Nemesia ligulara

Watlenhergia annularis

Cle retum papulosum subsp. papulosum

Oncosiphon suffruticosum

Senecio arenarius

Tetragonia microptera

Ifloga paronychioides

Ifloga sp. (Struck 285)

Gazania lichtensteinii

Lasiospermum brachyglossum

Wahlentergia prostrata

Oxalis obmusa

Trachyandra flexifolia

Chlorophyzum crassinerve

Total cover $[\%]$

Plot 6. Diverse ephemeral vegetation with therophytes and some geophytes on disturbed NW slope, $1 \%$ inclination, on alluvial plain (glacis)

\begin{tabular}{|c|c|c|c|c|c|c|c|c|c|c|c|}
\hline \multirow[t]{2}{*}{ Taxon } & \multirow[t]{2}{*}{$\begin{array}{l}\text { Life } \\
\text { form }\end{array}$} & \multicolumn{3}{|c|}{$\begin{array}{l}\text { Cover }[\%] \\
\text { at anthesis }\end{array}$} & \multicolumn{3}{|c|}{$\begin{array}{c}\text { Duration of flowering } \\
\text { [days] }\end{array}$} & \multicolumn{3}{|c|}{$\begin{array}{l}\text { Maximum number of } \\
\text { flowers }\end{array}$} & \multirow[t]{2}{*}{$\begin{array}{c}\text { Floral } \\
\text { unit }\end{array}$} \\
\hline & & 1985 & 1986 & 1987 & 1985 & 1986 & 1987 & 1985 & 1986 & 1987 & \\
\hline Senecio arenarius & $\mathrm{T}$ & 2.5 & 3 & 5 & 101 & 60 & +57 & 1800 & 2275 & 5500 & $\mathrm{Ca}$ \\
\hline Grielum humifusum & $\mathbf{T}$ & + & 3 & 3 & 41 & 53 & +42 & 92 & 1730 & 2120 & \\
\hline Clereium pupulosium subsp. pupulosum & $\mathbf{T}$ & 3 & + & $\mathbf{r}$ & 54 & 29 & $?$ & 480 & 47 & $?$ & \\
\hline Heliophila deserricola & $\mathbf{T}$ & 0.5 & 1.5 & 4 & 54 & +61 & +32 & 800 & 2300 & 2300 & \\
\hline Mesembnamthemum guerichianum & $\mathbf{T}$ & 0.5 & 20 & $(7 *)$ & $38+$ & 64 & - & 300 & 2590 & - & \\
\hline Diascia namaquensis long-spurred form & $\mathbf{T}$ & 0.3 & + & + & 54 & +42 & +16 & 400 & 588 & $?$ & \\
\hline Manulea cheiramthus & $\mathbf{T}$ & 0.3 & + & + & 63 & +24 & $?$ & 960 & 57 & $?$ & Inf \\
\hline Galenia surcophsilla & $\mathbf{T}$ & $\mathbf{r}$ & 6 & + & 61 & 58 & - & 35 & 25000 & - & Inf \\
\hline Pharnaceum croceum & $\mathbf{T}$ & + & 0.2 & + & $35+38$ & 45 & +32 & 600 & 70() & $?$ & Inf \\
\hline Dimorphotheca simuata & $\mathbf{T}$ & + & + & 1 & $39+21$ & 49 & +67 & 60 & 234 & $?$ & $\mathrm{Ca}$ \\
\hline Leysera senella & $\mathbf{T}$ & + & + & 1 & $84+$ & 78 & $+94+$ & 315 & 565 & 18.50 & $\mathrm{Ca}$ \\
\hline Lstononis brachyloba & $\mathbf{T}$ & + & + & 1 & $35+30$ & 39 & +32 & 4) & 195 & 474 & \\
\hline Oncosiphon piluliferum & $\mathbf{T}$ & + & + & 0.5 & $48+12$ & 44 & +67 & 1300 & 550 & 550 & $\mathrm{Ca}$ \\
\hline Wahlenbengia prostrata & $\mathbf{T}$ & + & + & 0.5 & $3.3+21$ & 40 & 72 & 610 & 1900 & $29(x)$ & \\
\hline Lessertia diffusa & $\mathbf{T}$ & + & + & + & - & 32 & 17 & - & 25 & 4 & Inf \\
\hline Nemesia azurea & $\mathbf{T}$ & + & + & + & 49 & +56 & +42 & 95 & 270 & 4) & \\
\hline Nemesia versicolor & $\mathbf{T}$ & + & + & + & 54 & +56 & +24 & 255 & 540 & $?$ & \\
\hline Polycarens pubescens & $\mathbf{T}$ & + & + & + & 31 & +49 & +24 & 14 & 246 & $?$ & $\operatorname{lnf}$ \\
\hline Silene clandestina & $\mathbf{T}$ & + & + & + & $?$ & $?$ & $?$ & $?$ & $?$ & $?$ & \\
\hline Helichnsum oblusum & $\mathbf{T}$ & + & + & $r$ & 68 & 27 & 8 & 145 & 45 & 9 & $\operatorname{lnf}$ \\
\hline Senecio cardaminifolius & $\mathbf{T}$ & + & + & $r$ & 35 & 49 & +11 & 35 & 62 & 16 & $\mathrm{Ca}$ \\
\hline Oncosiphon grandifforum & $\mathbf{T}$ & + & r & 0.5 & $68+$ & $8.5+$ & 83 & 680 & 244 & 700 & $\mathrm{Ca}$ \\
\hline Arclotis fasfuesa & $\mathbf{T}$ & + & $r$ & + & $42+5$ & $5+12$ & +43 & 6 & 2 & 14 & $\mathrm{Ca}$ \\
\hline Pelargonium senecioides & $\mathbf{T}$ & + & $r$ & $r$ & 58 & 11 & 17 & 9 & 1 & 1 & \\
\hline Hermannia gariepina & $\mathbf{T}$ & $\mathbf{r}$ & + & $r$ & $34+$ & 20) & - & 5 & 9 & - & \\
\hline Lasiospenmum brachiglossum & $\mathbf{T}$ & $\mathbf{r}$ & + & r & 5()$+5$ & 46 & 9 & 31 & 18 & 5 & $\mathrm{Ca}$ \\
\hline Dimorphotheca polyptera & $\mathrm{T}$ & $\mathbf{r}$ & $r$ & + & $14+1.3$ & 50 & +32 & 4 & 8 & 10 & $\mathrm{Ca}$ \\
\hline
\end{tabular}




\begin{tabular}{|c|c|c|c|c|c|c|c|c|c|c|c|}
\hline Zaluzianskya benthamiana & $\mathrm{T}$ & + & + & - & 11 & +35 & - & 2 & 46 & - & $\ln f$ \\
\hline Tribulus zeyheri & $\mathrm{T}$ & + & $\mathbf{r}$ & - & 26 & 58 & - & 13 & 6 & - & \\
\hline Tetragonia microptera & $\mathrm{T}$ & $\mathbf{r}$ & $\mathbf{r}$ & - & 89 & - & - & 60 & - & - & Inf \\
\hline Ifloga paronychioides & $\mathrm{T}$ & + & r & - & 29 & 18 & - & 70 & 15 & - & \\
\hline Oncosiphon suffruticosum & $\mathrm{T}$ & r & - & - & 4 & - & - & 3 & - & - & Int \\
\hline Aizoon canariense subsp. paucandrum & $\mathrm{T}$ & - & $\mathrm{r}$ & - & - & +42 & - & - & 265 & - & Inf \\
\hline Conicosia elongata & G & + & + & 0.5 & 24 & 21 & +42 & 6 & 3 & 18 & \\
\hline Oxalis grammopetala & G & + & + & + & 34 & +24 & $?$ & 25 & $?$ & $?$ & \\
\hline Gladiolus orchidiflorus & G & - & $\mathbf{r}$ & + & - & 20 & 13 & - & 15 & 6 & \\
\hline Albuca cooperi & G & - & $\mathbf{r}$ & I & - & 14 & 11 & - & 1 & 1 & \\
\hline Homeria schlechteri & G & - & $\mathbf{r}$ & $\mathbf{r}$ & - & 14 & - & - & 4 & - & \\
\hline Ornithoglossum vulgare & G & - & $\mathbf{r}$ & $\mathbf{r}$ & - & 18 & 24 & - & 3 & 3 & \\
\hline Ornithogalum secundum & G & - & $\mathbf{r}$ & $\mathbf{r}$ & - & 5 & 16 & - & 7 & 14 & \\
\hline Total cover [\%] & & 25 & 50 & 25 & & & & & & & \\
\hline
\end{tabular}

Total cover [\%]

* dried fructiferous plants of the previous season.

Ch, chamaephytes; NP, nanophanerophytes; T, therophytes; G, geophytes; Ca, capitula; Cy, cyathia; Inf, inflorescences or flower aggregates. 